\title{
The association of CAG repeat length polymorphisms of androgen receptor gene and spermatogenesis impairment in several Indonesian men
}

\author{
Purnomo Soeharso , Arfianti ${ }^{\#}$, Nukman Moeloek ${ }^{*}$
}

\begin{abstract}
Abstrak
Infertilitas pria paling banyak disebabkan oleh gangguan proses spermatogenesis. Androgen merupakan hormon yang sangat penting pada proses spermatogenesis. Aksi biologis hormon androgen terjadi melalui interaksi dengan reseptor androgen (RA) yang merupakan protein regulator transkripsi di dalam nukleus. Ekson 1 gen RA mengandung pengulangan trinukleotida CAG yang bersifat polimorfik. Polimorfisme pengulangan trinukleotida CAG ini diduga mempengaruhi aktivitas reseptor androgen. Penelitian meliputi isolasi DNA dari darah tepi dan amplifikasi fragmen pengulangan trinukleotida CAG gen RA dengan teknik PCR. Penentuan panjang pengulangan CAG gen RA dilakukan dengan elektroforesis pada gel poliakrilamid $6 \%$ yang mengandung zat pendenaturasi. Dari penelitian ini didapatkan perbedaan jumlah pengulangan CAG gen reseptor androgen antara pria oligozoospermia/azoospermia $(24,3 \pm 3,4)$ dan pria normozoospermia $(22,7 \pm 2,7)$. Berdasarkan uji t untuk sampel tidak berpasangan, perbedaan jumlah pengulangan $C A G$ pada gen reseptor androgen antara kedua kelompok tersebut bermakna secara statistik $(p=0,031)$. Namun tidak ditemukan hubungan antara jumlah pengulangan $C A G$ gen $R A$ dengan konsentrasi sperma $\left(r_{s}=-0,038 ; p=0,775\right)$. Ini menunjukkan bahwa peningkatan jumlah pengulangan CAG gen RA bukan merupakan penyebab utama gangguan spermatogenesis. (Med J Indones 2004; 13: 215-20)
\end{abstract}

\begin{abstract}
Spermatogenesis impairment is the main cause of infertility in men. Androgen is believed to play a critical role in regulating spermatogenesis. Androgen acts by binding to the androgen receptor (AR) which is a protein regulator of DNA transcription. Exon 1 of AR gene contains a CAG repeat length polymorphism and it is believed to interfere AR function. This study includes DNA isolation from peripheral blood and amplification of CAG repeat fragments by PCR method. CAG repeat lengths were determined by electrophoresis on $6 \%$ denaturing gel polyacrylamide. We found that the mean CAG repeat lengths were $24,3 \pm 3,4$ in oligozoospermic/azoospermic men and $22,7 \pm 2,7$ in normozoospermic men. The difference in CAG repeat length between the two groups was statistically significant ( $p=0,031, t$-test). Nevertheless, there was no correlation between CAG repeat lengths and sperms concentration $\left(r_{s}=-0,038 ; p=0,775\right)$. This result suggest that the expansion of CAG repeat length was not the main cause of spermatogenesis impairment. (Med J Indones 2004; 13: 215-20)
\end{abstract}

Keywords : androgen receptor, CAG repeat, IVF/ICSI, male infertility.

Infertility includes $13-18 \%$ of married couples, in which spermatogenesis impairment is the main cause of infertility in men. ${ }^{1}$ Androgen is believed to play a critical role in regulating spermatogenesis as reduction of intratestiscular androgen results in defective spermatogenesis. The biological activities of androgen is manifested through their binding to the androgen receptor (AR). Nevertheless in some cases, men with impaired spermatogenesis have normal serum androgen

\footnotetext{
*Department of Medical Biology, Faculty of Medicine, University of Indonesia, Jakarta, Indonesia

\# Biomedical Postgraduate Program, Faculty of Medicine, University of Indonesia, Jakarta, Indonesia
}

level. In the majority of men with such disorder, the etiology of disorder is still poorly understood and diagnosed as idiopathic infertility. In this study therefore, attention has been focused on abnormalities in the $A R$ as a possible cause of idiopathic infertility. ${ }^{1,2}$

Androgen act by binding to the androgen receptor (AR) that eventually lead to regulation of transcription processes of downstream androgen-dependent genes. Thus, the abnormality of AR may affect sperm production through the modulation of androgen signaling. The AR is coded by a gene located in the $\mathrm{X}$ chromosome at Xq 11-12. Exon 1 of AR gene contains a CAG repeat length polymorphisms representing 
variable lengths of polyglutamine stretch. Expansion of more than 40 repeats potentially leads to spino and bulbar muscular atrophy (SBMA) or Kennedy disease, a fatal neuromuscular disease. In addition to the neurological symptom typical to this disease, some patients indicate signs of reduced AR function in the form of low virilization, testiscular atrophy, oligozoospermia or azoospermia and reduced fertility. ${ }^{3}$

CAG repeat length polymorphisms have also been linked to prostate cancer risk in some studies. Giovannucci et $a .^{4}{ }^{4}$ reported that the risk of prostate cancer was inversely proportional to the CAG repeat length. Studies by Hardy et al. ${ }^{5}$, indicated that men with shorter CAG repeats are diagnosed with prostate cancer at an earlier age than men with longer CAG repeats. Therefore it could be assumed that spermatogenesis is potentially affected by the changes of CAG repeat lengths of androgen receptor gene, as it is an exquisitely androgen-dependent process. ${ }^{3}$

Various studies have been done to examine the correlation between CAG repeat length polymorphisms and spermatogenesis impairment. Tut et al. ${ }^{6}$, Dowsing et al. ${ }^{\text {, }}$ Yoshida et al. ${ }^{8}$, Patrizio et al. ${ }^{9}$ and Sasagawa et $a l .{ }^{10}$ showed an association between longer CAG repeat and spermatogenesis impairment. But others have reported that there were no association between the length of CAG repeat and spermatogenesis impairment. $^{11,12}$ Thus, no consistent results of studies have been found in CAG repeat length polymorphisms. Recent study by Dadze et al. ${ }^{11}$ suggested ethnic differences as a possible explanation for these contradictory findings. Based on this consideration in the present study we analyse the CAG repeat length polymorphisms in Indonesian men and correlated them with spermatogenesis impairment.

\section{METHODS}

\section{Patients}

Patients were those presented themselves for infertility investigations and treatment to the Departement of Medical Biology, Faculty of Medicine, University of Indonesia, after signing informed consent. The subjects include 59 men with unproven fertility, consisting of 34 men with spermatogenesis impairment ranging from oligozoospermia (sperm concentration of $<20 \times 10 \% \mathrm{ml}$ ejaculate) to azoospermia (no spermatozoa in ejaculate) and 25 normozoospermic men (sperm concentration of $>20 \times 106 / \mathrm{ml}$ ejaculate).
Patients who had hypopituitarism, varicocele, infective or obstructive syndrome of genital tracts were excluded from this study. Patients were ordered for serum FSH, LH and testosterone levels which were measured by ELISA microplate reader methods. The normal range is $=0,8-13,0 \mathrm{mIU} / \mathrm{mL}, 7,0-23,0$ $\mathrm{mIU} / \mathrm{mL}$ and $3,5-8,6 \mathrm{ng} / \mathrm{mL}$ for $\mathrm{FSH}, \mathrm{LH}$ and testosterone level respectively.

\section{Amplification of CAG repeat fragment of the AR gene using PCR method}

DNA genom were extracted from peripheral blood samples using Wizard $^{\circledR}$ Genomic DNA Purification kit. One hundred samples of genomic DNA were amplified by PCR technique using AR-I primer (5'TCC AGA ATC TGT TCC AGA GCG TGC -3') and AR-II primer (5'- GCT GTG AAG GTT GCT GTT CCT CAT -3'). The PCR mixture was performed in a total reaction volume of $50 \mu \mathrm{L}$, containing $0,2 \mu \mathrm{M}$ of each primer, $200 \mu \mathrm{M}$ of dNTP, $1 \mathrm{X}$ PCR buffer containing $1,5 \mathrm{mM} \mathrm{MgCl} 2$, and 0,25 $\mathrm{U}$ of Taq polimerase (Promega). Amplification was carried out in a Gene Amp. PCR System 9700 (Perkin Elmer) with PCR condition of $95^{\circ} \mathrm{C}$ for 5 minutes, continued by 35 cycles of $95^{\circ} \mathrm{C}$ for 1 minute, $60^{\circ} \mathrm{C}$ for 1 minute dan $72^{\circ} \mathrm{C}$ for 1,5 minute, and final extension of $72^{\circ} \mathrm{C}$ for 10 minutes. The PCR products were determined electrophoretically in $2 \%$ gel agarose ${ }^{13}$.

\section{Determination of CAG repeat number of the AR gene}

Two $\mu \mathrm{L}$ of PCR products were mixed with $6 \mu \mathrm{L}$ of formamide loading buffer $(0,05 \%$ bromophenol blue, 0,05\% xylene cyanol FF, $20 \mathrm{mM}$ EDTA and 95\% formamide). The samples were heated at $95^{\circ} \mathrm{C}$ for 3 minutes and chilled in ice directly. $5 \mu \mathrm{L}$ of these samples were loaded onto a $6 \%$ denaturing gel polyacrylamide and run in vertical electrophoresis (UI home made) at $300 \mathrm{~V}$ for 8 hours. ${ }^{13}$ The number of CAG repeat were determined by comparing the detected PCR fragment to standard fragments that were run in parallel to the samples and serve as molecular size marker. A number of samples were subjected for sequence analysis to confirm the validity of the measurement results.

\section{Statistical Analysis}

The number of CAG repeat was denoted as mean \pm SD. Statistical analysis was performed using the SPSS for 
Windows version 11,0. All variables were checked for normal distribution using one-sample KolmogorovSmirnov test for goodness of fit. The independent t-test was used to compare the CAG repeat number and serum level of FSH, $\mathrm{LH}$ and testosterone between the two groups. One-way ANOVA was used to compare the CAG repeat number among azooospermic, oligozoospermic and normozoospermic men. Pearson's and Spearman's coefficient correlation was used to find the correlation between the CAG repeat number and sperm concentration as well as between CAG repeat number and serum level of FSH, LH and testosterone. A probability of $\mathrm{p}<0,05$ was considered to be statistically significant.

\section{RESULTS}

The CAG repeat fragments of AR gene were determined by PCR amplification of DNA genom and electrophoresed them in $6 \%$ denaturing gel polyacrilamide. The size of the uppermost strongest band was determined as compared to samples of known size (Figure 1). A total of 12 different CAG repeat lengths (alleles), ranging from 19 to 31 repeats were detectable in 34 oligozoospermic/azoospermic men (Figure 2). Of 25 normozoospermic men, 9 different CAG repeat lengths ranging from 16 to 28 repeats were detectable. The mean number of CAG repeats in oligozoospermic/azoospermic group was $24,3 \pm 3,4$ while in normozoospermic group was $22,7 \pm 2,7$ respectively (Table 1). Comparison of CAG repeat length between oligozoospermic/azoospermic men and normozoospermic men was statistically significant $(p=0,031, t$-test $)$. The largest repeat number in oligozoospermic/azoospermic men was 28 , whereas in normozoospermic men was 31 (Figure 2). Both alleles were found in low frequency ( $2,9 \%$ in oligozoospermic / azoospermic men and $4 \%$ in normozoospermic men). The smallest repeat numbers in oligozoospermic / azoospermic men was 19 , whereas in normozoospermic men was 16. Both alleles were also found in low frequency $(2,9 \%$ in oligozoospermic/azoospermic men and $4 \%$ in normozoospermic men). The most common CAG repat number in oligozoospermic/azoospermic men was $25(17,6 \%)$, whereas in normozoospermic men was $23(32 \%)$.

Serum FSH and LH level of oligozoospermic/ azoospermic men were higher than normozoospermic men $(\mathrm{p}=0,000$ and 0,021 respectively, Table 2$)$. In contrast, there was no difference in the level of serum testoterone between the two groups $(\mathrm{p}=0,231)$. According to Spearman's coefficient correlation, there was no correlation between the CAG repeat number and sperm concentration $\left(\mathrm{r}_{\mathrm{s}}=-0,038 ; \mathrm{p}=0,775\right)$ as well as between the CAG repeat number and hormonal level $\left(r_{\mathrm{s}} \mathrm{FSH}=0,204, \mathrm{p}=0,152 ; \mathrm{r} \mathrm{LH}=\right.$ $0,245, \mathrm{p}=0,083 ; \mathrm{r}_{\mathrm{s}}$ testosterone $\left.=0,030 ; \mathrm{p}=0,834\right)$

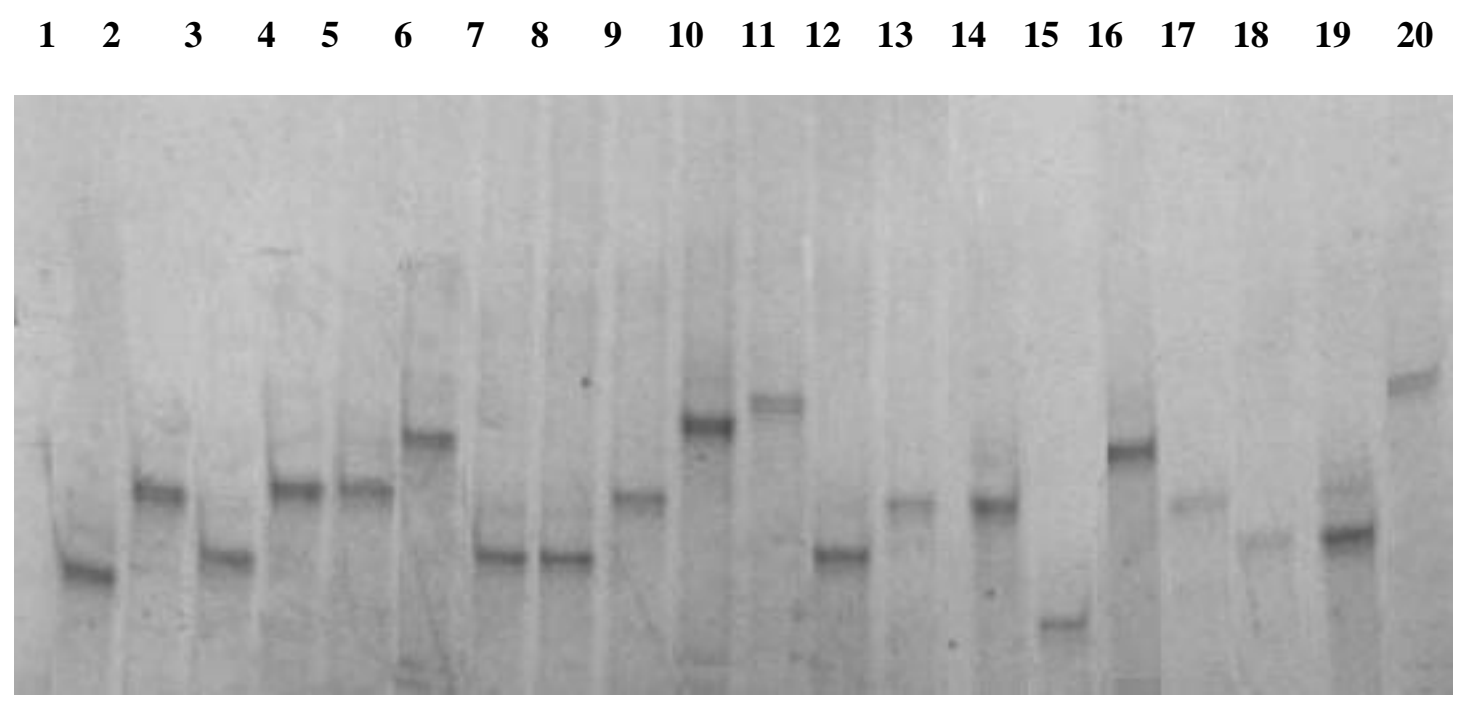

Figure 1. CAG repeat number of the AR gene in oligozoospermic/azoospermic men and normozoospermic men. The CAG repeat fragments of the AR gene were amplified by PCR, electrophoresed in $6 \%$ denaturing gel polyacrylamide and stained with silver nitrate. Differences of the CAG repeat number among samples were shown. Slot 1 to 20 were sample with 21, 25, 22, 25, 25, 28, 22, $22,25,29,30,22,25,25,19,28,25,23,23,31$ CAG repeats respectively. 
Table 1. Comparison of the CAG repeat length of the AR gene between normozoospermic, oligozoospermic and azoospermic men.

\begin{tabular}{lccccc}
\hline \multicolumn{1}{c}{ Sperm concentration } & $\mathbf{N}$ & $\begin{array}{c}\text { Mean } \\
\text { (repeat) }\end{array}$ & $\begin{array}{c}\text { Standard } \\
\text { deviation }\end{array}$ & Min & Max \\
\hline Azoospermia & 9 & 23,00 & 2,739 & 20 & 27 \\
Oligozoospermia & 25 & 24,96 & 3,494 & 19 & 31 \\
Oligozoospermia/azoospermia & 34 & 24,29 & 3,459 & 19 & 31 \\
Normozoospermia & 25 & 22,68 & 2,719 & 16 & 28 \\
\hline
\end{tabular}

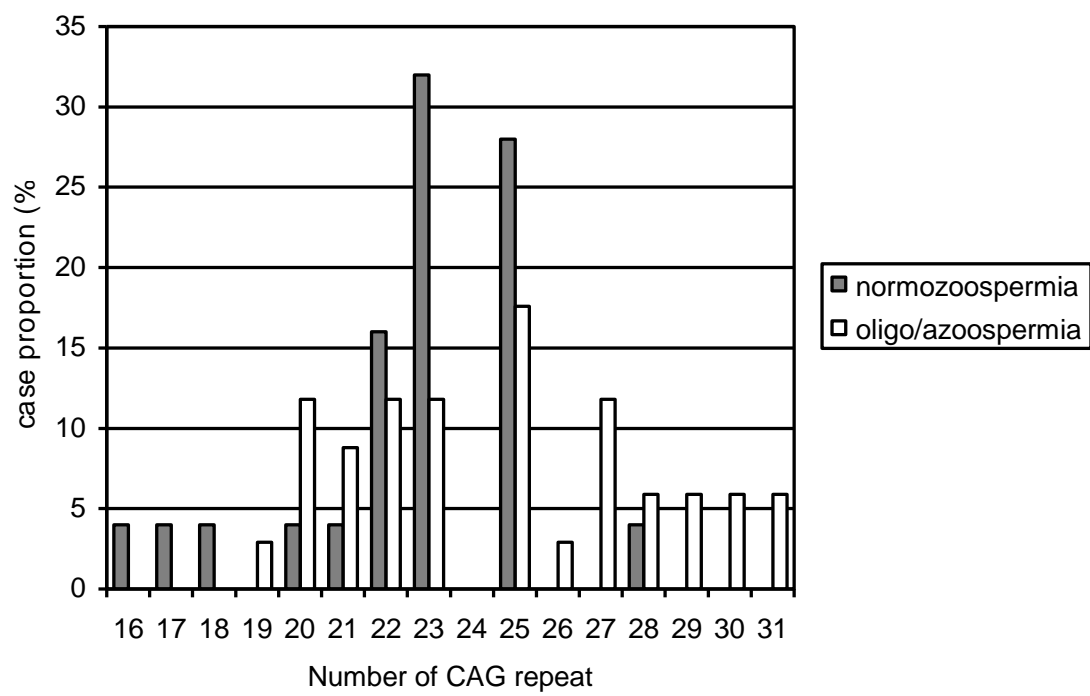

Figure 2. Distribution of CAG repeat number in oligozoospermic/azoospermic men and normozoospermic men.

Table 2. The comparison of hormonal level between oligozoospermic men and normozoospermic men

\begin{tabular}{lllcr}
\hline & & N & Mean (ng/mL) & Standard deviation \\
\hline \multirow{2}{*}{ FSH } & Oligozoospermia/azoospermia & 34 & 9,9 & 5,99 \\
& Normozoospermia & 17 & 4,3 & 2,13 \\
\multirow{3}{*}{ LH } & Oligozoospermia/azoospermia & 34 & 10,2 & 4,64 \\
& Normozoospermia & 17 & 7,3 & 2,57 \\
& Oligozoospermia/azoospermia & 34 & 4,1 & 0,82 \\
& Normozoospermia & 17 & 3,6 & 1,58 \\
\hline
\end{tabular}

\section{DISCUSSION}

In this study it was found that the number of CAG repeat length in oligozoospermic / azoospermic men were significantly higher than those in normozoospermic men. This result indicated that there was a relationship between the CAG repeat length and spermatogenesis impairment. Similar results of investigation in Chinese $^{6}$ and Japanese ${ }^{8}$ infertile men were in agreement with this study, although the control groups used in these studies were fertile men without assessment of sperm concentration, that may lead to bias the data, as about $30 \%$ of fertile men may have subnormal sperm count.

In case the classification of men with spermatogenesis impairment was based on their degree of spermatogenesis impairment, the CAG repeat length was only 
distinguishable in oligozoospermic men if it is compared to normozoospermic men. Furthermore, there was no statistically difference in CAG repeat length as azoospermic men were compared to normozoospermic men. Several factors may contribute to these results such as the limited size number of azoospermic men or genetic factors underlying the cause of azoospermia. Microdeletions of $Y$ chromosome are believed to cause azoospermia. RBM and DAZ gene were among genes located on the long arm of $\mathrm{Y}$ chromosome. Deletion of these gene were known to be the etiology of azoospermia ${ }^{1}$. Pryor et al. reported that $7 \%$ of infertile men may have deletion on both genes. ${ }^{14}$ Therefore, screening on $\mathrm{Y}$ chromosome microdeletion is necessary in the next study. In the mean time von Eckardsteins et al. ${ }^{15}$ demonstrated the association of CAG repeat length with sperm concentration in normal men. It was shown taht CAG repeat length was inversely correlated to sperm concentration. However, Dadze et al. ${ }^{11}$ and Thangaraj et al. ${ }^{12}$ showed no significant difference in the CAG repeat length between normal and infertile men.

Although the CAG repeat length differ significantly in the two groups, no correlation of CAG repeat length and sperm concentration exist. This data suggest that the extension of CAG repeat in the AR gene in this study was not the main cause of spermatogenesis impairment. The CAG repeat length did not correlate to serum FSH, LH and testosterone, suggesting that the variation of the CAG repeat length is independent to hormonal level.

Our present study demonstrates that serum FSH and LH in oligozoospermic / azoospermic men are significantly higher than normozoospermic men. Elevated serum FSH in men with spermatogenesis impairment may be a consequence of spermatogenic failure and elevated serum LH is common in AIS patients that may result from the insensitivity of pituitary cells to serum testosterone. Nevertheless, the serum level of testosterone did not differ significantly in the two groups. It was shown conclusively that spermatogenesis impairment in this study was not doe to the decreasing of testosterone level.

The mechanisms by which longer CAG repeat size is potentially cause spermatogenesis impairment is still poorly understood. Kazemi et al. ${ }^{16}$ and Tut et al. ${ }^{6}$ reported that $\mathrm{CAG}$ repeat length of AR correlate inversely with its transactivation function. A possible mechanism for this observation is linked to the difference in interaction with ARA24. ${ }^{17}$ ARA24 is a novel nuclear $G$ protein, which acts as a coactivator for AR. The interaction between polyglutamine segment of AR and ARA24 become stronger as the number of glutamines decreases, thereby increasing transactivation capability.

It is assured recently that infertile men with a variety of spermatogenesis defect are capable of gaining and looking after children by the assistance of ICSI (intracytoplasmic sperm injection). Despite this remarkable clinical success, ICSI has a potential risk for transmitting Kennedy disease. ${ }^{9}$ A recent report by Cram et al. ${ }^{18}$ evaluated the CAG repeat inheritance in female offspring conceived after ICSI. Although $95 \%$ of the ICSI daughters inherit AR allele with the same number of CAG repeat as their fathers, it was also found that in the remaining $5 \%$ of them, the CAG repeat may undergo either contraction or expansion. In expansion cases, the son of ICSI daughter is not affected merely by spermatogenesis defect, but is suffering from Kennedy disease as well. In the future it is recommended that screening for the length of CAG repeat in the AR should become part of the preICSI genetic testing. ${ }^{9}$

\section{CONCLUSIONS}

Although CAG repeat lengths in oligozoospermic / azoospermic men were significantly higher than in normozoospermic men, no correlation of CAG repeat lengths and sperm concentrations were found. This result indicate that CAG repeat length polymorphisms is not the main cause of spermatogenesis impairment in several Indonesian men.

\section{REFERENCES}

1. Seshagiri PB. Molecular insights into the causes of male infertility. J BioSci. 2001; 26(suppl): 429-35.

2. McLachlan RI, Wreford NG, O'Donnell L, de Kretser DM, Robertson DM. The endocrine regulation of spermatogenesis : Independent roles for testosterone and FSH. J Endocrinol . 1996; 148: 1-9.

3. Quigley CA, De Bellis A, Marschke KB, El Awady Mk, Wilson EM, French FS. Androgen reseptor defect: Historical, clinical and molecular perspectives. Endocrin Rev. 1995; 16: 271-321.

4. Giovannucci E, Stampfer MJ, Krithivas K, Brown M, Brufsky A, et al. The CAG repeat within the androgen receptor gene and its relationship to prostate cancer. Proc Natl Acad Sci USA 1997; 94: 3320-3.

5. Hardy DO, Scher HI, Bogenreider T, Sabbatini P, Zhang $\mathrm{Z}$, et al. Androgen receptor $\mathrm{CAG}$ repeat lengths in 
prostate cancer: correlation with age of onset. J Clin Endocrinol Metab. 1996; 82: 4400-5.

6. Tut TG, Ghadessy FJ, Trifiro MA, Pinsky L, Yong EL. Long polyglutamine tracts in the androgen receptor are associated with reduced transactivation, impaired sperm production and male infertility. J Clin Endocrinol Metab. 1997; 82: 3777-82.

7. Dowsing AT, Yong EL, Clark M, McLachlan RI, de Kretser DM, Trounson AD. Linkage between male infertility and trinucleotide repeat expansion in the androgen receptor gene. Lancet 1999; 354: 640-3.

8. Yoshida K, Yano M, Chiba K, Honda M, Kitahara S. CAG repeat length in the androgen receptor gene is enhanced in patients with idiopathic azoospermia. Urology 1999; 54: 1078-81.

9. Patrizio P, Leonard DGB, Chen K, Hernandex-Ayup S, Trounson AD. Larger trinucleotide repeat size in the androgen receptor gene of infertile men with extremely severe oligozoospermia. J Androl. 2001; 22: 444-8.

10. Sasagawa I, Suzuki Y, Ashida J, Nakada T, Muroya K, Tsutomuo. CAG repeat length analysis and mutation screening of the androgen receptor gene in Japanese men with idiopathic azoospermia. J Androl. 2001; 22: 804-8.

11. Dadze S, Wieland C, Jakubiczka S, Funke K, Schröder E, Royer-Pokora B, et al. The size of the CAG repeat in exon 1 of the androgen receptor gene shows no significant relationship to impaired spermatogenesis in an infertile caucasoid sample of german origin. Mol Hum Reprod. 2000; 6: 207-14.
12. Thangaraj K, Joshi MB, Reddy AG, Gupta NJ, Chakravarty B, Singh L. CAG repeat expansion in the AR gene is not associated with male infertility in Indian populations. J Androl. 2002; 23: 815-8.

13. Sambrook J, Russel DW. Molecular cloning: A laboratory manual. $2^{\text {nd }}$ edition. Cold Spring Harbor Laboratory Press, New York; 2001.

14. Pryor JL, Kent-first M, Muallem A, von Vergen AH, Nolten WE, Meisner L, Roberts KP. Microdeletion in the Y choromosome of infertile men. N Engl J Med. 1997; 336: 534-39.

15. von Eckardstein S, Syska A, Gromoll J, Kamischke A, Simoni M, Nieschlag E. Inverse correlation between sperm concentration and number of androgen receptor CAG repeats in normal men. J Clin Endocrinol Metab. 2001; 86: 2585-90.

16. Kazemi-Esfarjani P, Trifiro MA, Pinsky L. Evidence for a repressive function of the long polyglutamine tract in the human androgen receptor: possible pathogenetic relevance for the $(\mathrm{CAG})_{\mathrm{n}}$-expanded neuronopathies. Hum Mol Genet. 1995; 4: 523-7.

17. Hsiao PW, Lin DL, Nakao R, Chang C. The linkage of Kennedy's neuron disease to ARA24, the first identified androgen receptor polyglutamine region-associated coactivator. J Biol Chem. 1999; 374: 20229-34.

18. Cram DS, Song B, McLachlan RI, Trounson AO. CAG trinucleotide repeats in the androgen receptor gene of infertile men exhibit stable inheritance in female offspring conceived after ICSI. Mol Hum Reprod. 2000; 6: 861-6. 